Pierre Emmanuel Charles Saber Davide Barbar

\section{Toll-like receptors: a link between mechanical ventilation, innate immunity and lung injury?}

Received: 11 February 2010

Accepted: 12 February 2010

Published online: 16 April 2010

(C) Copyright jointly held by Springer and ESICM 2010

This editorial refers to the article available at: doi:10.1007/s00134-010-1799-3.

P. E. Charles $(\bowtie) \cdot$ S. D. Barbar

Service de Réanimation Médicale, Hôpital Le Bocage, CHU de Dijon, Dijon, France

e-mail: pierre-emmanuel.charles@chu-dijon.fr

P. E. Charles · S. D. Barbar

Laboratoire Interactions Muqueuses Agents pathogènes (LIMA), EA562, UFR Médecine, Université de Bourgogne, Dijon, France

In critically ill patients, the lung is exposed to various aggressors. Mechanical stress resulting from mechanical ventilation (MV), systemic inflammation and bacteria are probably the main insults that the lung has to face. An accumulation of experimental evidence now supports the hypothesis that large tidal volumes $\left(\mathrm{V}_{\mathrm{T}}\right)$ along with the absence of positive end-expiratory pressure promotes lung injury (i.e. ventilator-induced lung injury) [1]. The clinical relevance of ventilator-induced lung injury has been illustrated by studies showing that MV in the conditions listed above is an independent predictor of death in patients with established lung injury as well as in those at risk of injury [2, 3]. Sepsis, aspiration, haemorrhagic shock, major surgery and trauma are therefore high-risk conditions since they are likely to trigger an inflammatory response in the host. In addition, clinical and experimental findings support the theory that both insults could act synergistically and cause lung inflammation and injury [4]. The underlying mechanisms of the so-called "two-hit" paradigm have been investigated. The lung can be "primed" by mechanical stretch, which drives an increased inflammatory response to a second insult such as exposure to microbial agents or to systemic inflammation [5]. It has been experimentally demonstrated that pulmonary epithelial cells and alveolar macrophages subjected to a combination of cyclic stretch and cytokines such as tumour necrosis factor- $\alpha$ and interleukin- $1 \beta$ or bacterial molecules such as lipopolysaccharide (LPS) release substantially more inflammatory mediators than cells kept static [6-8]. Interestingly, cell stretch activates similar intracellular signalling pathways (NF- $\kappa \mathrm{B}, \mathrm{MAPK}$ ) as those induced by proinflammatory cytokines [9]. Cooperation and synergism between transcriptional factors is currently thought to be the underlying molecular mechanism that causes the combined effect of the two insults [10].

It has now been well established that microbial products are recognized by the innate immune system via patternrecognition receptors, essentially represented by the Toll-like receptor (TLR) family. TLR4, for example, is essential for LPS recognition by mammalian cells. Interestingly, alveolar macrophages from mechanically ventilated rabbits have been shown to be much more responsive to LPS than those from spontaneously breathing animals [11], and to be associated with increased CD14 expression, enhancing LPS recognition by TLR4.

In this month's issue of Intensive Care Medicine, Villar et al. [12] present the results of an experimental study aimed at determining the impact of MV on lung inflammation in animals with previous abdominal sepsis and surgery, a classical "two-hit" model of ventilator-induced lung injury. A caecal ligation and puncture was performed in previously healthy rats. Surviving animals were then left breathing spontaneously or subjected to one of two distinct MV strategies, mimicking a clinically relevant scenario. The authors showed that a lung protective ventilation strategy (low $\mathrm{V}_{\mathrm{T}}$ with positive end-expiratory 
pressure) reduced lung inflammation and damage. In contrast, an injurious MV strategy (high $\mathrm{V}_{\mathrm{T}}$ and zero endexpiratory pressure) caused substantial lung injury and increased inflammatory cytokine gene expression. Further experiments were conducted to investigate the underlying mechanism with a special emphasis on the TLR4 signalling pathway. An injurious MV was found to increase lung TLR4 expression and to reduce the expression of the "antiinflammatory" $\mathrm{I} \kappa \mathrm{B} \alpha$. The authors concluded that, compared with lung-protective ventilator settings, an injurious MV strategy promotes an inflammatory lung response and worsens tissue damage in a context of extrapulmonary sepsis. They suggested that TLR4 overexpression could account, at least in part, for the increased inflammatory response reported in animals receiving high tidal volumes.

These findings are in accordance with recently published reports. It has been shown, for example, that even a brief MV with low $\mathrm{V}_{\mathrm{T}}$ induces TLR2 and TLR4 gene expression in previously healthy animals, together with mild lung inflammation [13, 14]. It has also been reported that the genetic absence of TLR4 in mice decreases lung injury and especially PMN recruitment in a similar "twohit" model (high $\mathrm{V}_{\mathrm{T}} \mathrm{MV}$ plus LPS challenge) [15].

The study of Villar et al. together with these reports illustrate well that lung tissue "primed" by a first hit such as sepsis or endotoxaemia becomes hyperresponsive to MV, particularly if it is injurious. This in itself supports the use of a protective MV strategy in patients with primed lungs. In addition, the study of Villar et al. provides a hypothesis for an underlying molecular mechanism for MV-induced lung injury and a possible therapeutic target, TLR4. It remains unclear as to how the MV-induced TLR4 overexpression may induce lung injury. It could well be that increased TLR4 renders lungs more responsive to LPS or that they become sensitive to endogenous TLR4 ligands, the so-called "alarmins". Among the possible endogenous TLR4 ligands are heatshock proteins and the high mobility group box 1 (HMGB-1) [16]. From the work of Villar et al., no definite conclusions can be drawn about the relative role of lung over-distension induced by high $\mathrm{V}_{\mathrm{T}}$ versus the repeated opening and closing of alveolar airways resulting from the zero end-expiratory pressure in this group. Additional experiments are needed to explore this issue. Finally, the potential role of other TLRs, especially TLR2 should also be investigated given its relevance regarding lung immunity and inflammation, and the high prevalence of gram-positive pathogens in severe pneumonia.

The findings of Villar et al. add to the intriguing notion that ventilator settings could directly influence lung TLR expression and modulate TLR-dependent inflammatory pathways. The modulation of TLR pathways has been used as an experimental approach to decrease systemic inflammation and death, in caecal ligation and puncture and pneumonia models [17]. It is worth noting that the lack of TLR4 in mice with gram-negative pneumonia has been associated with a reduction in lung inflammation and injury, without impacting on bacterial clearance [18]. Similar findings have been reported in other sepsis models, but antibiotics were given to the infected animals [19]. Accordingly, the beneficial effect of TLRs should, however, not be overlooked. Bacterial recognition is necessary to initiate an efficient and prompt host response against bacterial pathogens. A complete TLR blockade should, therefore, not interfere with this critical step in the innate immune response to an infectious insult. Antibiotics should be administered simultaneously to keep bacterial growth in check. Importantly, TLRs have been shown to be important for lung healing and repair [20]. Altogether, these experimental observations suggest that tight regulation of the signalling pathway within the lung is required throughout the course of sepsis in an attempt to alleviate bacterial insult and tissue injury. MV can deeply alter this flimsy equilibrium by inducing inappropriate TLR expression. All these data add new insights into the underlying mechanisms by which MV promotes bacterial growth and injury within the lung [21-23].

The findings of Villar et al. emphasize the extent to which a lung-protective MV strategy could protect the lung against the deleterious effects of an excessive inflammatory response associated with over-activation of the TLR4 pathway. Further improvements can be envisaged with the future development of therapies aimed at modulating TLR signalling pathways within the lung in a way that clearly favours the host, that is to say without compromising bacterial clearance and lung repair. These experimental observations also highlight the need for careful adjustment of ventilator settings in patients with a high risk of lung injury, and the importance of protective MV strategies in patients with systemic inflammation and supposedly "normal" lungs.

\section{References}

1. Dreyfuss D, Saumon G (1998) Ventilator-induced lung injury: lessons from experimental studies. Am J Respir Crit Care Med 157:294-323
2. Acute Respiratory Distress Syndrome Network (2000) Ventilation with lower tidal volumes as compared with traditional tidal volumes for acute lung injury and the acute respiratory distress syndrome. N Engl J Med 342:1301-1308
3. Gajic O, Frutos-Vivar F, Esteban A, Hubmayr RD, Anzueto A (2005) Ventilator settings as a risk factor for acute respiratory distress syndrome in mechanically ventilated patients. Intensive Care Med 31:922-926 
4. Dreyfuss D, Soler P, Saumon G (1995) Mechanical ventilation-induced pulmonary edema. Interaction with previous lung alterations. Am J Respir Crit Care Med 151:1568-1575

5. Altemeier WA, Matute-Bello G, Frevert CW, Kawata Y, Kajikawa O, Martin TR, Glenny RW (2004) Mechanical ventilation with moderate tidal volumes synergistically increases lung cytokine response to systemic endotoxin. Am J Physiol Lung Cell Mol Physiol 287:L533-L542

6. Pugin J, Dunn I, Jolliet P, Tassaux D, Magnenat JL, Nicod LP, Chevrolet JC (1998) Activation of human macrophages by mechanical ventilation in vitro. Am J Physiol 275:L1040L1050

7. Mourgeon E, Isowa N, Keshavjee S, Zhang X, Slutsky AS, Liu M (2000) Mechanical stretch stimulates macrophage inflammatory protein-2 secretion from fetal rat lung cells. Am J Physiol Lung Cell Mol Physiol 279:L699-L706

8. Oudin S, Pugin J (2002) Role of MAP kinase activation in interleukin- 8 production by human BEAS-2B bronchial epithelial cells submitted to cyclic stretch. Am J Respir Cell Mol Biol 27:107-114

9. Pugin J (2003) Molecular mechanisms of lung cell activation induced by cyclic stretch. Crit Care Med 31:S200-S206

10. Altemeier WA, Matute-Bello G, Gharib SA, Glenny RW, Martin TR, Liles WC (2005) Modulation of lipopolysaccharide-induced gene transcription and promotion of lung injury by mechanical ventilation. J Immunol 175:3369-3376

11. Moriyama K, Ishizaka A, Nakamura M, Kubo H, Kotani T, Yamamoto S, Ogawa EN, Kajikawa O, Frevert CW, Kotake Y, Morisaki H, Koh H, Tasaka S, Martin TR, Takeda J (2004) Enhancement of the endotoxin recognition pathway by ventilation with a large tidal volume in rabbits. Am J Physiol Lung Cell Mol Physiol 286:L1114-L1121
12. Villar J, Cabrera N, Casula M, Flores C, Valladares F, Muros M, Blanch L, Slutsky AS, Kacmarek R (2010) Mechanical ventilation modulates tolllike receptor signaling pathway in a sepsis-induced lung injury model. Intensive Care Med. doi: 10.1007/s00134-010-1799-3

13. Vaneker M, Joosten LA, Heunks LM, Snijdelaar DG, Halbertsma FJ, van Egmond J, Netea MG, van der Hoeven JG, Scheffer GJ (2008) Low-tidalvolume mechanical ventilation induces a toll-like receptor 4-dependent inflammatory response in healthy mice. Anesthesiology 109:465-472

14. Hillman NH, Moss TJ, Kallapur SG, Bachurski C, Pillow JJ, Polglase GR, Nitsos I, Kramer BW, Jobe AH (2007) Brief, large tidal volume ventilation initiates lung injury and a systemic response in fetal sheep. Am J Respir Crit Care Med 176:575-581

15. Hu G, Malik AB, Minshall RD (2010) Toll-like receptor 4 mediates neutrophil sequestration, lung injury induced by endotoxin, hyperinflation. Crit Care Med 38:194-201

16. Adib-Conquy M, Cavaillon JM (2007) Stress molecules in sepsis and systemic inflammatory response syndrome. FEBS Lett 581:3723-3733

17. Roger T, Froidevaux C, Le Roy D, Reymond MK, Chanson AL, Mauri D, Burns K, Riederer BM, Akira S, Calandra T (2009) Protection from lethal gram-negative bacterial sepsis by targeting toll-like receptor 4 . Proc Natl Acad Sci U S A 106:2348-2352

18. Lee JS, Frevert CW, Matute-Bello G, Wurfel MM, Wong VA, Lin SM, Ruzinski J, Mongovin S, Goodman RB, Martin TR (2005) TLR-4 pathway mediates the inflammatory response but not bacterial elimination in $E$. coli pneumonia. Am J Physiol Lung Cell Mol Physiol 289:L731-L738
19. Spiller S, Elson G, Ferstl R, Dreher S, Mueller T, Freudenberg M, Daubeuf B, Wagner H, Kirschning CJ (2008) TLR4-induced IFN-gamma production increases TLR2 sensitivity and drives gram-negative sepsis in mice. J Exp Med 205:1747-1754

20. Jiang D, Liang J, Fan J, Yu S, Chen S, Luo Y, Prestwich GD, Mascarenhas MM, Garg HG, Quinn DA, Homer RJ, Goldstein DR, Bucala R, Lee PJ, Medzhitov R, Noble PW (2005) Regulation of lung injury and repair by toll-like receptors and hyaluronan. Nat Med 11:1173-1179

21. Charles PE, Piroth L, Desbiolles N, Lequeu C, Martin L, Portier H, Chavanet P (2002) New model of ventilator-associated pneumonia in immunocompetent rabbits. Crit Care Med 30:2278-2283

22. Charles PE, Martin L, Etienne M, Croisier D, Piroth L, Lequeu C, Pugin J, Portier H, Chavanet P (2004) Influence of positive end-expiratory pressure (PEEP) on histopathological and bacteriological aspects of pneumonia during low tidal volume mechanical ventilation. Intensive Care Med 30:2263-2270

23. Pugin J, Dunn-Siegrist I, Dufour J, Tissieres P, Charles PE, Comte R (2008) Cyclic stretch of human lung cells induces an acidification and promotes bacterial growth. Am J Respir Cell Mol Biol 38:362-370 